\title{
Education Management of Early Childhood Education Programs to Prepare Students toward Primary School in Globalization Era
}

\author{
Wiryanto $^{1}$, Sugi Hartono ${ }^{2, *}$ \\ ${ }^{1}$ Department of Primary Education, Universitas Negeri Surabaya, Surabaya, Indonesia \\ ${ }^{2}$ Department of Mathematics Education, Universitas Negeri Surabaya, Surabaya, Indonesia
}

Received July 21, 2020; Revised November 13, 2020; Accepted November 29, 2020

\section{Cite This Paper in the following Citation Styles}

(a): [1] Wiryanto, Sugi Hartono , "Education Management of Early Childhood Education Programs to Prepare Students toward Primary School in Globalization Era," Universal Journal of Educational Research, Vol. 8, No. 12A, pp. 7268 7273, 2020. DOI: 10.13189/ujer.2020.082509.

(b): Wiryanto, Sugi Hartono (2020). Education Management of Early Childhood Education Programs to Prepare Students toward Primary School in Globalization Era. Universal Journal of Educational Research, 8(12A), 7268 - 7273. DOI: 10.13189/ujer.2020.082509.

Copyright $\bigcirc 2020$ by authors, all rights reserved. Authors agree that this article remains permanently open access under the terms of the Creative Commons Attribution License 4.0 International License

\begin{abstract}
Early childhood education management aims to make the organization's management work well. One of the indicators of good early childhood education management is to provide effective services for early childhood education. In its development, we must know some factors in the management of early childhood education institutions to create the qualified generations. This article aims at analyzing the factor that plays a role in the success of the Early Childhood Education (PAUD) management in the globalization era. The method in this study is a cross sectional research accomplished by Multiple Regression Analysis which involved 50 PAUD staffs in Mojokerto city, East Java, Indonesia. The measuring technique in this research is questionnaire, a technique used to get the data by distributing questionnaire arranged by the researcher according to the purpose of the study. Closed test questions with five options are used in this research. The result shows that there was a partially significant influence on the entire independent variables: curriculum, standard of competence, educator, facilities and infrastructure. Facilities and infrastructure variables had the highest beta as many as $33.7 \%$, which showed the dominant influence toward the success of PAUD management. Thus, all factors of this model in this research showed that influenced the success of PAUD management.
\end{abstract}

Keywords Curriculum, Facilities and Infrastructure, PAUD Management

\section{Introduction}

Entering the third millennium, Indonesia is faced with the challenge of preparing for the new era, namely globalization that penetrates all life aspects. In monitoring the child's development and the need of the early childhood education [1], it is clear that there are two things that need to be considered in early childhood education. They are (1) education materials and (2) the education method being used [2]. In both cases, teachers must be able to prepare well when teachers provide education for early childhood education. Besides that, to create the qualified generations, education has to be given to the early age child in this case is by Early Childhood Education (PAUD). It is the education that is given to the baby until six years old. PAUD is conducted as the basic education. It can be conducted through formal, non-formal, and/or informal education.

In efforts to develop PAUD schools, there are several factors that influence it, including the national basic curriculum and the national competency framework for early childhood. They are the guidelines that can be used in the arrangement of curriculum and syllabus (education planning) at schools. School-based curriculum (KTSP) is 
operational curriculum that is arranged and conducted by each school. Therefore, the good education management can create the qualified human resource (HR), and eventually they will be able to maintain the nation's existence worldwide [3].

Furthermore, the behavior of 1-5 years old children depends on the habit and along with their early stage is learned by playing [4]. This pattern is an effective way of stimulating the children's intelligence development by introducing them to the things shown by their guardians. In this case, like play should be the main element of an environment that aims to support toddlers' development.

Considering the big impact of the children's game, as mentioned above, the role of parents is one of the factors that need to provide a good and healthy place for their children to play. This intends to give the positive direction so that the negative things are not influencing the children's personality. The tendency of the children to ask all that they see, adults need to explain and give example wisely. It means that the game guide has to be able to give good explanation and avoid the bad words and attitude due to the nature of children, who easily imitate others [5]. Education defines the success of one's future in which childhood experiences, good or bad experiences, will all influence her/his later life. The very first experience in those early years is strongly defining the one's mental health in the future.

To achieve all those, ways or methods in giving the early childhood education by implanting the education about the behavior which is suitable to the students' development level are needed. In the end, the students will ready toward study in next level, mainly in primary school.

Based on the explanation above, researchers are interested in doing deeper research with the aim of analyzing the factor that plays a role in the success of the Early Childhood Education (PAUD) management in the globalization era.

\section{Materials}

\subsection{Early Childhood Education}

Early Childhood Education (PAUD) is a level of education before the basic education level [6]. A recent National Research Council (2000) report on early childhood education and intervention divides skill development into three areas: cognitive skills, school readiness, and social and emotional development [6]. For thus, PAUD is an effort of development that is aimed from the baby until six years old children, by giving education stimulation to prepare them for entering the further education, which is conducted in a formal, non-formal and informal way.

\subsection{Curriculum in Early Childhood Education}

The success of the learning process in an educational institution it cannot be regardless of the curriculum [7]. Curriculum is a series of plan and management of objective, content and material and the method used as the guideline of conducting the learning activity to achieve a certain education goal [8]. In early childhood, it is needed that education efforts cover stimulation program, guidance, nurture, and learning activities to develop many kinds of potency that is owned by children. It can be implemented through curriculum development $[9,10]$.

Curriculum is arranged to facilitate the development of several multi potencies, interest, language intelligence, cognitive, social, emotional, spiritual, and kinesthetic/psychomotor, and art of a child optimally which is suitable with the development and the uniqueness of each child [10]. The improvement of curriculum, included the early childhood education curriculum, is done continuously through stages of assessment, socialization, advocacy, and implementation by the curriculum developer team, experts, practitioners, and coaches as well as the educational administration [11].

Besides that, formulation of curriculum management there needs to be support from the teachers, parents, school committee and community around. A good curriculum is prepared by the teacher who really understands curriculum, which is then communicated to all parties in the environment school. Based on research from Susilawati [12] stated that planning curriculum requirements can be done by holding a meeting at school and ask for input from the principal, teachers, foundations, and parents of students.

\subsection{Standard of Competence}

The activities of early childhood education institutions (PAUD) are implementing learning programs in accordance with predetermined curriculum references and learning strategies [13]. The development of learning aspects in early childhood education must refer to the standard of competence of early childhood, including: moral and religious values, physical or motoric, social and emotional, language, cognitive, and art [14]. Religious and moral values taught in early childhood are positive behavior, independence, discipline, honesty and other behaviors.

Habitual activities related to religious values must also be provided, such as mastery of daily prayers. In addition, educators must be able to stimulate physical and motoric development of children according to their developmental age. This can be done with various educational games. In this case, students also need to be able to develop social skills through the socialization process. Through this aspect, children are equipped with the ability to solve 
social problems they face, of course, through a process of habituation which is carried out continuously. For the language aspect, children are encouraged to master the ability to communicate according to their development period. Language skills seen from the child's developmental age can be categorized into two, namely the prelinguistic period (0-1 years) and the linguistic period (1-5 years). Skills in the arts can also be developed in music, dance, drawing arts, and other skills that provide aesthetic and artistic abilities for early childhood. Hopefully, all of these characters can support the basic competencies in the PAUD curriculum to be better.

\subsection{Educator}

PAUD educator is a professional who is obliged for planning, conducting learning process, and evaluating learning outcomes $[15,16]$, as well as the advisory, nurture, and protection of the students.

Teacher duties can be seen in Law no. 20 of 2013 article 39 states that education personnel are tasked with carrying out administration, management, development, supervision and technical services to support the educational process in educational units [17]. Teachers in PAUD not only teach during lessons, but also manage their own curriculum management. This can be seen by holding a meeting before entering school and this meeting contains a lesson plan for the next year. In addition, teachers also understand what good learning is so that PAUD students are happy and comfortable both inside and outside the classroom.

Based on Saracho and Spodek [18] that the early childhood teachers' professional development affects the quality of early childhood programs and predicts the children's developmental outcomes. The strongest relationship exists between the number of years of education and the appropriateness of a teacher's classroom behavior. The other reviews of research concluded that better outcomes for young children are the result of the teachers' background and quality of education $[19,20]$, such as the presence of a bachelor's degree in early childhood education.

\subsection{Facilities and Infrastructure}

Infrastructure management is equipment that is directly used to support the process of learning activities [21]. The management of these infrastructure facilities is managed by the school for the benefit of the learning process so that its use can run effectively and efficiently in PAUD. According to Purwadi [22], the purpose of managing facilities and infrastructure in schools is to provide professional services related to educational facilities and infrastructure so that the learning process can run effectively and efficiently.

PAUD Facilities is a set of educational materials and media to support the learning process by playing [23], so that it is effective in terms of optimizing the child's development. The principle of PAUD facilities is very safe for children, suitable with their age and development. Thus they can develop their ability, containing the education values, utilizing the surrounding potency and resources including the useful scraps, interesting and motivating the child to explore and experiment, sustainable or not easily broken. Early Childhood Education Infrastructure is many kinds of tools, equipment, or stuffs supporting the learning activities administration, nurturing, and protection of them optimally. PAUD infrastructure principles are safe, convenience, fulfilling the health criteria for children, using the surrounding potency and resources.

\section{Methods}

There are two variables used in this research, namely dependent variable and independent variable. Independent variable is curriculum, Standard of competence, educator, facilities and infrastructure. Dependent variable in this research is the success of PAUD management in globalization era. The populations are 200 from the PAUD staffs in Mojokerto city, East Java, Indonesia. This research is using Total Sampling Study. It is the sampling technique when all of the populations are used as sample and it is well known as census [24]. After using random sampling, the researcher choose 50 staffs for become a subject in this study.

Based on the purpose of this study, the researchers are using cross sectional, a research that is conducted at one time and in order to find the relation of the independent variable (risk factor) toward dependent variable (effect). Correlation method used to find the relation among the variables being researched. The measuring technique in this research is questionnaire, a technique used to get the data by distributing questionnaire arranged by the researcher according to the purpose of the study. Closed test questions with five options are used in this research.

In this research, Multiple Regression Analysis is used. Multiple linear regression analysis, this analysis is used to determine the relationship between two or more independent variables $(\mathrm{X} 1, \mathrm{X} 2, \ldots \mathrm{Xn})$ on the dependent variable $(\mathrm{Y})$ simultaneously. This coefficient shows how much the relationship that occurs between the independent variables (X1, X2, ..... Xn) simultaneously on the dependent variable $(\mathrm{Y})$. The value of $\mathrm{R}$ ranges from 0 to 1 , the value getting closer to 1 means that the relationship is getting stronger, conversely the value is getting closer to 0 , the weaker the relationship is. This model is chosen because the researchers wanted to know how much the influence of curriculum is, standard of competence, educator, facilities and infrastructure to the success of the PAUD management in the globalization era, dominantly 
or partially.

\section{Results and Discussion}

\subsection{Simultaneous F Test}

From the analysis of SPSS for Windows version 16.0, the result of $\mathrm{F}$ test in this research is found. The result of simultaneous $\mathrm{F}$ test can be shown in Anova table as follows:

Table 1. Anova Table

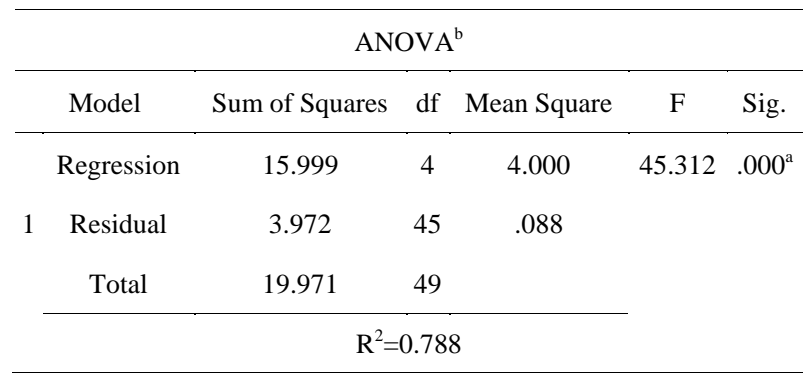

$\mathrm{F}$ test result shows that F-count is 45.312 . The F-table value with the degree of freedom $=n-k-1=50-4-1=45$ is 2.58. Because the F-count value $=45.312>$ F-table $=2.58$; therefore first hypothesis are accepted. It means that this model is successful in explaining dependent variable as a whole, how far the influence is on the independent variable. The result shows that the value of $\mathrm{R} 2=0.788$. It means that research variable curriculum, standard of competence, educator and facilities and infrastructure influenced the success of PAUD management, by determination value $\mathrm{R} 2=78.8 \%$ the rest of $12.2 \%$ is influenced by other variables.

\subsection{Partial T test}

$\mathrm{T}$ test analysis result is shown by the output of coefficient table from SPSS program. T test is done to test the meaning of regression coefficient from each independent variable. Partial $\mathrm{T}$ test result can be seen from the SPSS output in the form of coefficient table 2 below.

T-test result shows that t-count for curriculum variable is 2.389; standard of competence variable is 3.524; educator variable is 4.156; and facilities and infrastructure variable is 3.943. T-table value with the degree of freedom $=50-4-1=45$ by significant level $(\alpha)=5 \%$ is 1.679. T-count for the curriculum variable is $2.389>$ T-table value is 1.679; therefore Ha is accepted and Ho is rejected. It means curriculum as a dependent variable can explain the independent variable, the success of PAUD management in the globalization era $(\mathrm{Y})$.

T-count value for standard of competence variable is $3.524>$ t-table value $=1.679$; $\mathrm{Ha}$ is accepted and $\mathrm{Ho}$ is rejected. It means standard of competence variable as a dependent variable can explain the independent variable, the success of PAUD management in the globalization era (Y). T-count value for educator variable is $4.156>\mathrm{t}$-table value $=1.679 ; \mathrm{Ha}$ is accepted and $\mathrm{Ho}$ is rejected. It means educator variable as a dependent variable can explain the independent variable, the success of PAUD management in the globalization era $(\mathrm{Y})$.

T-count value for facilities and infrastructure variable is $3.943>$ t-table value $=1.679$; $\mathrm{Ha}$ is accepted and $\mathrm{Ho}$ is rejected. It means facilities and infrastructure variable as a dependent variable can explain the independent variable, the success of PAUD management in the globalization era (Y).

Table 2. Multiple Linear Regression Results

\begin{tabular}{c|c|c|c|c|c|c|c}
\hline \multirow{2}{*}{ Model } & \multicolumn{9}{c}{$\begin{array}{c}\text { Unstandardized Coefficients } \\
\text { Standardized Coefficients }\end{array}$} & \multirow{2}{*}{$\mathrm{t}$} & \multirow{2}{*}{ Sig. } & \multicolumn{2}{c}{ Collinearity Statistics } \\
\cline { 2 - 5 } & $\mathrm{B}$ & Std.Error & Beta & $\begin{array}{c}\text { Toler } \\
\text { ance }\end{array}$ & VIF \\
\hline Constant & -.48 & .34 & & -1.4 & .16 & & .50 \\
\hline Curriculum & .21 & .08 & .22 & 2.3 & .02 & .50 & 1.9 \\
\hline Standard of competence & .30 & .08 & .28 & 3.5 & .00 & .67 & .73 \\
\hline Educator & .29 & .07 & .32 & 4.1 & .00 & .73 & 1.3 \\
\hline $\begin{array}{c}\text { Facilities and } \\
\text { infrastructure }\end{array}$ & .33 & .08 & .33 & 3.9 & .00 & .60 & 1.6 \\
\hline
\end{tabular}




\subsection{Dominant Test}

Dominant test can be seen from the Standardized Coefficients Beta result from the SPSS output. It can be seen from the table below:

Table 3. Coefficient Beta Table

\begin{tabular}{ccc}
\hline No. & Variable & $\begin{array}{c}\text { Standardized } \\
\text { Coefficients Beta }\end{array}$ \\
\hline 1 & Curriculum & 0,224 \\
\hline 2 & Standard of competence & 0,286 \\
\hline 3 & Educator & 0,323 \\
\hline 4 & Facilities and Infrastructure & 0,337 \\
\hline
\end{tabular}

Coefficient Beta value of facilities and infrastructure variable is 0.337 . It means facilities and infrastructure contribute to the success of PAUD management in the globalization era $(\mathrm{Y})$. Since the partial influence of facilities and infrastructure variable $=33.7 \%$ is higher from other variables thus facilities and infrastructure variable dominantly influence toward the success of PAUD management in the globalization era.

Based on the results, the curriculum is the lowest factor in influencing this management. In line with this, Mulyaniasih [25] also said that the competence abilities of PAUD children are strongly influenced by Educators' Understanding, Educator Competencies, and Facilities \& Infrastructure. For this reason, PAUD managers have an obligation to provide encouragement to both managers, teachers and children to improve all their potential abilities and creativity in learning. So that when students enter a higher level, namely in primary school, they are ready and able to follow lessons well.

Besides that, teachers also have a fairly high impact after infrastructure. For that, it is necessary to pay attention to and improve its management. This is in line with Firdaus and Ansori [26], tutor educational process which has multiple roles, but also as a mentor who encourages potential, develops alternatives, and mobilizes students in developing their learning. It is emphasized if the tutor has a high commitment, it can be expected learners will achieve satisfactory academic achievement.

\section{Conclusions}

Based on the ANOVA table results, the F-count value show that $45.312>$ F-table $=2.58$. It means that this model is successful in explaining dependent variable as a whole, how far the influence is on the independent variable. Thus, we can conclude that there was a partially significant influence on the entire independent variables: curriculum, standard of competence, educator, facilities and infrastructure. Furthermore, the partial influence of facilities and infrastructure variable $=33.7 \%$ is higher from other variables, for that the facilities and infrastructure variables had the highest beta and showed the dominant influence toward the success of PAUD management.

Of the four factors in this research model, namely Curriculum, Standard of competence, Educator, Facilities and Infrastructure, can be maximized by PAUD managers in schools, so that students who enter the primary school level can follow and have good abilities. Further research should be able to add other variables which are thought to affect the potential abilities of children, such as parental attention, motivation, attitudes, teaching and learning processes and others.

\section{REFERENCES}

[1] Siswono, T. Y. E., Kohar, A. W., Hartono, S., Rosyidi, A. H., Kurniasari, I., \& Karim, K. (2019). Examining Teacher Mathematics-related Beliefs and Problem-solving Knowledge for Teaching: Evidence from Indonesian Primary and Secondary Teachers. International Electronic Journal of Elementary Education, 11(5), 493-506.

[2] Prawoto, B., Hartono, S., \& Fardah, D. (2018, July). Prospective teachers' difficulties in second order linier differential equation: a case of constructing methods in solving a non-homogeneous problem. In IOP Conf. Series (Vol. 1108, No. 012002, pp. 1-5).

[3] Siswono, T. Y. E., Hartono, S., Kohar, A. W., Karim, K., \& Lastiningsih, N. (2019). How do Prospective Teachers Manage Students' Learning of Mathematics?. TEM Journal, 8(2), 677.

[4] Finlayson, T. L., Siefert, K., Ismail, A. I., \& Sohn, W. (2007). Maternal self-efficacy and 1-5-year-old children's brushing habits. Community dentistry and oral epidemiology, 35(4), 272-281.

[5] Jackson, G. T., Boonthum, C., \& Mc NAMARA, D. S. (2009). iSTART-ME: Situating extended learning within a game-based environment. In Proceedings of the workshop on intelligent educational games at the 14th annual conference on artificial intelligence in education (pp. 59-68). Brighton. UK: AIED.

[6] Currie, J. (2001). Early childhood education programs. Journal of Economic perspectives, 15(2), 213-238.

[7] Knight, P. T. (2001). Complexity and curriculum: A process approach to curriculum-making. Teaching in higher education, 6(3), 369-381.

[8] Grossman, S. (1999). Examining the origins of our beliefs about parents. Childhood Education, 76(1), 24-27

[9] Siswono, T. Y. E., Kohar, A. W., \& Hartono, S. (2018, January). Designing Tasks to Examine Mathematical Knowledge for Teaching Statistics for Primary Teachers. In Journal of Physics: Conference Series (Vol. 947, No. 1, p. 012008). IOP Publishing.

[10] Iswahyudi, P., Wijayati, D. T., Soedjarwo, S., \& Hartono, S. (2019). Influence of Graduation Quality and Flight Training as a Vocational School on International Standard Job Opportunities. TEM Journal, 8(4), 1456. 
[11] Samples, B., \& Astuti, R. (2002). Revolusi Belajar Untuk Anak, Paduan Belajar Sambil Bermain untuk membuat pikiran Anak-Anak Anda, Jakarta: Jalmar Prees.

[12] Susilawati \& Dewi, R. (2013). Pengelolaan Kurikulum Pembelajaran Tematik dengan MetodeSpider Web (Studi Kasus di Sekolah Alam Ungaran /SAUNG). Educational Management 2 (I): 136-141.

[13] Onwu, G. O., \& Mogari, D. (2004). Professional development for outcomes-based education curriculum implementation: the case of UNIVEMALASHI, South Africa. Journal of Education for Teaching, 30(2), 161-177.

[14] Rozalena, R., \& Kristiawan, M. (2017). Pengelolaan pembelajaran paud dalam mengembangkan potensi anak usia dini. JMKSP (Jurnal Manajemen, Kepemimpinan, dan Supervisi Pendidikan), 2(1).

[15] Bredekamp, S. \& Rosegrant, T. (Eds). (1992). Reaching Potentials: appropriate Curriculum and Assessment for Young Children. V-1. Washington, DC.: NAEYC.

[16] Hagger, H., Burn, K., Mutton, T., \& Brindley, S. (2008). Practice makes perfect? Learning to learn as a teacher. Oxford Review of Education, 34(2), 159-178.

[17] Mughiyati, J., \& Waluyo, E. (2014). Manajemen kurikulum paud berbasis alam (Studi Kasus di Paud Alam Ar-Ridho Semarang Tahun Pelajaran 2013/2014). BELIA: Early Childhood Education Papers, 3(1).

[18] Saracho, O. N., \& Spodek, B. (2007). Early childhood teachers' preparation and the quality of program outcomes. Early child development and care, 177(1), 71-91.

[19] Howes, C. (1995) Reconceptualizing the early childhood work force, in: S. W. Helburn (Ed.) Cost, quality, and child outcomes in child care centers (Technical report) (Denver,
CO, University of Colorado at Denver, Department of Economics, Center for Research in Economic and Social Policy), 159-170. Available online at: http://ist-socrates.ber keley.edu/ iir/cscce/pdf/teacher_summary.pdf

[20] Bowman, B., Donovan, M. S. \& Burns, S. (Eds) (2000) Eager to learn: educating our preschoolers (Washington, DC, National Research Council). Available online at: http://books.nap.edu/books/0309068363/html/261.html

[21] Khikmah, A., \& Mukminin, A. (2017). The Readiness of the Early Childhood Education Institution Establishment in Terms of the Availability of Facilities and Infrastructure (A Case Study of playgroup Aisyiyah, Kabupaten Kudus). BELIA: Early Childhood Education Papers, 6(1), 1-5.

[22] Purwadhi, M. (2019). The role of education management, learning teaching and institutional climate on quality of education: evidence from Indonesia. Management Science Letters, 9(9), 1507-1518.

[23] Bergen, D. (2002). The role of pretend play in children's cognitive development. Early Childhood Research \& Practice, 4(1), n1.

[24] Jolly, G. M. (1969). Sampling methods for aerial censuses of wildlife populations. East African Agricultural and Forestry Journal, 34(sup1), 46-49.

[25] Mulyaniasih, Y. (2015). Pengaruh pemahaman pendidik tentang anak usia dini, kompetensi pendidik dan sarana prasarana terhadap kemampuan potensi anak pada PAUD An-Nuur Sleman tahun pelajaran 2013/2014. Wiyata Dharma: Jurnal Penelitian dan Evaluasi Pendidikan, 3(2), 88-97.

[26] Firdaus, N. M., \& Ansori, A. (2019). Optimizing Management of Early Childhood Education in Community Empowerment. Journal of Nonformal Education, 5(1), 89-96. 